\title{
The Canadian Policy on the Protection of Foreign Investment and the Canada-China Bilateral Investment Treaty
}

\author{
Gilbert Gagné \\ Bishop's University, Sherbrooke, Canada \\ Email: gilbert.gagne@ubishops.ca
}

How to cite this paper: Gagné, G. (2019). The Canadian Policy on the Protection of Foreign Investment and the Canada-China Bilateral Investment Treaty. Beijing Law Review, 10, 361-377. https://doi.org/10.4236/blr.2019.103021

Received: February 12, 2019

Accepted: April 16, 2019

Published: April 19, 2019

Copyright ( 2019 by author(s) and Scientific Research Publishing Inc. This work is licensed under the Creative Commons Attribution International License (CC BY 4.0).

http://creativecommons.org/licenses/by/4.0/

\section{cc) (i) Open Access}

\begin{abstract}
For a trading nation such as Canada, access to foreign markets has long been a key concern. In 2012, the Canadian government concluded a bilateral investment treaty (BIT) with China, so as to better protect Canada's investments in this big expanding market. China's communist regime, coupled with the importance of the country, has seemingly caused the Canada-China BIT to differ from the Canadian BIT model, both in terms of substantive provisions and the investor-state dispute settlement mechanism. Drawing on a legal-political analytical approach, the article: 1) looks at some key provisions on investment protection in the Canada-China BIT and 2) discusses the ways in which this BIT marks a departure in Canadian foreign investment policy. It also considers disagreements among legal scholars and commentators as to the implications of these differences, particularly with respect to the non-reciprocal character of the BIT to China's advantage.
\end{abstract}

\section{Keywords}

Canada-China Bilateral Investment Treaty (BIT), Canadian BIT Model, Investment Protection, Investor-State Dispute Settlement, Most-Favoured-Nation (MFN) Treatment

\section{Introduction}

For a trading nation such as Canada, trade policy has long been a key concern of its foreign policy. In today's economy, the close link between investment and trade is also recognized. Foreign direct investment (FDI) is particularly important for trade in services, because many of these can only be "traded" through a commercial presence (investment) in a foreign market. As the biggest of the emerging powers, China has long attracted a great deal of interests in terms of 
economic opportunities. Yet, China's authoritarian and non-democratic political regime, coupled with a judicial system seen as opaque and less than reliable, have led Western countries, including Canada, to better guarantee the security of their investments in the Middle Kingdom.

The primary means by which Western countries have sought to protect their foreign investments has been through the conclusion of bilateral investment treaties (BITs), especially with developing countries. After nearly all industrialized countries belonging to the Organization for Economic Cooperation and Development (OECD), ${ }^{1}$ Canada concluded a BIT with China in 2012. The BIT between Canada and China is considered in this article on the basis of the model used by the Canadian government for the negotiation of BITs with various countries throughout the world. The article: 1) looks at some key provisions on investment protection in the Canada-China BIT and 2) discusses the ways in which this BIT marks a departure in Canadian foreign investment policy. The article argues that China's attractiveness as the most important emerging power, coupled with the Canadian eagerness to receive Chinese investments, put Canada in a position of demandeur. These elements explain Canada's willingness to depart in some key instances from its investment template in order to reach a BIT with the Middle Kingdom. In turn, such departures from the Canadian BIT model have led to disagreements among legal scholars as to their implications, notably as regards the non-reciprocal character of the BIT in China's favour.

The structure of the article is as follows. Section 2 briefly mentions the history of BITs and of Canada's policy on the protection of foreign investment, the key features of Canadian international investment agreements (IIAs), and the countries with which the Canadian government has concluded IIAs. Section 3 begins with the elements that distinguish the Canada-China BIT within the universe of Canadian BITs, presents the figures and context of Canada-China investments, and highlights the key moments of the negotiations of the Canada-China BIT and its minimal duration. Section 4 focuses on the key differences between the Canadian BIT model and the Canada-China BIT with regard to substantive provisions, while Section 5 concentrates on the procedural provisions for dispute settlement. A conclusion ensues.

\section{BITs and Canadian Foreign Investment Protection Policy and Program}

The protection of foreign investment has been a central objective of many industrialized countries. This objective has been pursued mostly through the ne${ }^{1}$ The OECD is an intergovernmental organization that consists of a forum for policy discussion and coordination for now 36, mostly high-income, countries. These are: Australia, Austria, Belgium, Canada, Chile, the Czech Republic, Denmark, Estonia, Finland, France, Germany, Greece, Hungary, Iceland, Ireland, Israel, Italy, Japan, Korea, Latvia, Lithuania, Luxembourg, Mexico, the Netherlands, New Zealand, Norway, Poland, Portugal, Slovakia, Slovenia, Spain, Sweden, Switzerland, Turkey, the United Kingdom, and the United States. Among OECD members, only Ireland and the United States have not concluded a BIT with China. In the second half of the 1990s, the OECD hosted the failed negotiations for a Multilateral Agreement on Investment, whose key objective was to provide more uniform and effective rules on the liberalization and protection of foreign investment, in lieu of the existing BIT regime. 
gotiation and conclusion of BITs, particularly with developing countries. The primary rationale of BITs has been to protect investments from developed countries in developing and/or non-Western countries, whose judicial systems have been perceived as unsuitable or untrustworthy to secure such protection. The first modern BIT was signed between Germany and Pakistan in 1959. By the late-1960s, BITs came to include one further key element to protect foreign investors, in the form of investor-state dispute settlement mechanisms. These entitle foreign investors to direct, binding, and enforceable international arbitration, enabling them to be compensated in case government measures contravene treaty obligations and adversely affect their returns.

This development was prompted by the establishment in 1966 of the International Centre for Settlement of Investment Disputes (ICSID), an entity attached to the World Bank Group, which followed the adoption of the Washington or ICSID Convention (ICSID Convention). Such development, in turn, has been associated with another primary rationale of BITs, namely, the depoliticization of investment disputes. Under the traditional doctrine of diplomatic protection, foreign investors had to rely on their home states to raise their claims with host countries. Direct arbitration between a private entity and a state government avoids elevating an investment dispute to one between two sovereign states, so as to keep it to a lower level and, arguably, to lead to a more legal-based outcome. ${ }^{2}$

BITs were not particularly common until the mid-1980s, as developing countries generally insisted on their sovereign right to regulate foreign investment. Since, with the rise of neo-liberalism and the Washington Consensus, ${ }^{3}$ BITs have proliferated. From the mid-1990s, preferential trade agreements (PTAs) have also included chapters and/or provisions on the liberalization and protection of foreign investment. At the end of 2017, 2946 BITs had been concluded, with now a significant proportion of them negotiated between developing countries, as well as 376 other IIAs, ${ }^{4}$ most taking the form of bilateral free trade agreements (FTAs) ${ }^{5}$ (UNCTAD, 2018: p. 88). ${ }^{6}$

As for many countries, the structure of, as well as the provisions and exceptions in, Canadian IIAs conform to a standard model and, thus, are quite similar, ${ }^{2}$ Direct investor claims against sovereign states, nonetheless, have proved highly controversial, even leading to a backlash against investor-state arbitration.

${ }^{3}$ The Washington Consensus refers to a set of market-based economic policy prescriptions. Promoted by the International Monetary Fund and the World Bank Group, intergovernmental organizations both based in Washington, DC, it notably involves trade and investment liberalization. ${ }^{4}$ IIAs refer to both BITs and PTAs with investment provisions. The latter, which mainly take the form of FTAs, may also be referred to as treaties with investment provisions (TIPs) or preferential trade and investment agreements (PTIAs).

${ }^{5}$ PTAs could take the form of either FTAs, customs unions, common markets, or economic unions. ${ }^{6}$ There is a vast literature on the history and evolution of BITs and other treaties for the protection of foreign investment, as well as on the associated provisions, jurisprudence, and issues. See notably: Newcombe \& Paradell (2009); Dolzer \& Schreuer (2012); Salacuse (2015); Collins (2016); Sornarajah (2017); Bonnitcha, Poulsen, \& Waibel (2017); Schill, Tams, \& Hofmann (2018). On investor-state arbitration more specifically, see: Dugan, Rubins, Wallace Jr, \& Sabahi (2008); Waibel, Kaushal, Chung, \& Balchin (2010); McLachlan, Shore, \& Weiniger (2017); Lim, Ho, \& Paparinskis (2018). 
except for some countries' preferences and, at times, precedents. Canada began negotiating BITs, known as Foreign Investment Promotion and Protection Agreements (FIPAs), in 1989. It formulated its first BIT model in 1994, based on the investment chapter of the North American Free Trade Agreement (NAFTA). The model was updated in 2004 (FIPA Model), ${ }^{7}$ in response to concerns over the implementation of NAFTA's investment provisions. In this respect, from the turn of the $21^{\text {st }}$ century, Canada's BIT program has integrated the concern for the protection of Canadian investments abroad with Canada's interests as FDI recipient (McIlroy, 2004: p. 644; Côté, 2012: p. 298). Since, without leading to a formally revised BIT model, the template has evolved in some respects, although its main provisions have remained generally unaltered (Titi, 2013). ${ }^{8}$

As is usually the case in IIAs, most Canadian BITs and FTAs notably include a broad definition of investment, ${ }^{9}$ provisions to ensure national treatment, ${ }^{10}$ most-favoured-nation (MFN) treatment, ${ }^{11}$ minimum standard of treatment, ${ }^{12}$ the free transfer of capital, and to prohibit performance requirements, ${ }^{13}$ as well as unjustified and uncompensated expropriations. They further provide for investor-state dispute resolution.

As of March 2019, Canada had 37 BITs in force, with countries from various continents, including Argentina, China, Ivory Coast, Russia, Thailand, and Ukraine. ${ }^{14}$ Two were signed, but not yet effective; ${ }^{15}$ five BIT negotiations were ${ }^{7}$ On the Canadian BIT model, see: Newcombe (2004); McIlroy (2004); Côté (2006: pp. 488-497); Peterson (2006).

${ }^{8}$ On the evolution and features of Canadian investment protection policy, see Fortier (2009); Côté (2012); Newcombe (2017).

${ }^{9}$ The definition contained in the Canadian BIT model extends beyond physical assets, such as land and buildings, and beyond notions of FDI (based on ownership and control of assets) to include other concepts of asset ownership, such as concessions rights, debt instruments (i.e., portfolio investment), and any other tangible or intangible property and related property rights acquired or used for business purposes.

${ }^{10}$ Principle under which each party shall accord to investors of the other party or their investments treatment no less favourable than that it accords, in like circumstances, to its own investors or investments.

${ }^{11}$ Principle under which each party shall accord to investors of the other party or their investments treatment no less favourable than that it accords, in like circumstances, to investors or investments of a non-party.

${ }^{12}$ Principle under which each party shall accord to investors of the other party or their investments fair and equitable treatment, as well as full protection and security.

${ }^{13}$ Performance requirements are obligations imposed by a host state through law or regulation as pre-conditions to the establishment and/or maintenance of foreign investments. These usually require of foreign investors to conduct their business in a way considered beneficial to the host state's domestic economy, such as the export of a certain level or percentage of goods, or the purchase or use of a certain volume, value or proportion of products of domestic origin.

${ }^{14}$ Canada has BITs in force with the following countries and territories (with the years they were signed): Argentina (1991), Armenia (1997), Barbados (1996), Benin (2013), Burkina Faso (2015), Cameroon (2014), China (2012), Costa Rica (1998), Croatia (1997), the Czech Republic (1990, replaced (2009)), Ecuador (1996, terminated (2018)), Egypt (1996), Guinea (2015), Hong Kong (2016), Hungary(1991), Ivory Coast (2014), Jordan (2009), Kosovo (2018), Kuwait (2011), Latvia (1995, replaced (2009)), Lebanon (1997), Mali (2014), Mongolia (2016), Panama (1996), Peru (2006), Philippines (1995), Poland (1990), Romania (1996, replaced (2009)), Russia (1989), Senegal (2014), Serbia (2014), Slovakia (1990, replaced (2010)), Tanzania (2013), Thailand (1997), Trinidad and Tobago (1995), Ukraine (1994), Uruguay (1997), and Venezuela (1996).

${ }^{15}$ With Moldova and Nigeria. 
concluded; ${ }^{16}$ and 14 ongoing, two of which with India and Pakistan. ${ }^{17}$ In addition, Canada had 13 FTAs in force with various countries and groupings, including Mexico and the United States (through the NAFTA), Chile, South Korea, and the Comprehensive and Progressive Agreement for Trans-Pacific Partnership (CPTPP) $;^{18}$ while the Comprehensive Economic and Trade Agreement (CETA), with the European Union (EU), ${ }^{19}$ was applied provisionally. ${ }^{20}$ Two were signed: the Trans-Pacific Partnership (TPP) and the Canada-United States-Mexico Agreement (CUSMA); ${ }^{21}$ while nine FTA negotiations were ongoing, including with India and Japan ${ }^{22}$ (Government of Canada (a)).

\section{The Canada-China BIT and Investments, Negotiations, Duration}

Inasmuch as Canada has sought the protection of its investments in developing and/or non-Western countries, the Canada-China BIT is no exception. What makes this Canadian BIT stand apart is China's economic weight and Canada's eagerness to attract Chinese investments in its territory. The Canadian BIT with China is the only one involving a significant two-way economic relationship and in which Canada finds itself as the capital-importing partner. When other Canadian IIAs involve significant two-way economic relationships, these consist of FTAs and concern OECD countries. Such relationships have involved the United States (through the NAFTA) and, to a lesser degree, the main EU members (through the CETA), as well as Japan and Australia (through the CPTPP).

China ranked as the world's second largest economy and second largest recipient of FDI, receiving US\$168 billion in 2017. That same year, in terms of outward FDI, China ranked third in the world, with US\$ 102 billion (OECD, 2018: pp. 2, 5-6). In 2011, the stock of Canadian FDI in China was valued at ${ }^{16}$ With Albania, Bahrain, Madagascar, the United Arab Emirates, and Zambia.

${ }^{17}$ With the Democratic Republic of Congo, Gabon, Georgia, Ghana, India, Kazakhstan, Kenya, Macedonia, Mauritania, Mozambique, Pakistan, Qatar, Rwanda, and Tunisia.

${ }^{18}$ The CPTPP groups 11 countries: Australia, Brunei, Canada, Chile, Japan, Malaysia, Mexico, New Zealand, Peru, Singapore, and Vietnam.

${ }^{19}$ The European Union includes 28 member states: Austria, Belgium, Bulgaria, Croatia, Cyprus, the Czech Republic, Denmark, Estonia, Finland, France, Germany, Greece, Hungary, Ireland, Italy, Latvia, Lithuania, Luxembourg, Malta, the Netherlands, Poland, Portugal, Romania, Slovakia, Slovenia, Spain, Sweden, and the United Kingdom (pending the "Brexit" negotiations).

${ }^{20}$ Canada has FTAs in force with the following countries and groupings (with the years they were signed): Chile (1996), Colombia (2008), Costa Rica (2001), the CPTPP (2018), the European Free Trade Association (Iceland, Liechtenstein, Norway, Switzerland) (2008), Honduras (2013), Israel (1996), Jordan (2009), Korea (2014), Mexico (through NAFTA (1992)), Panama (2010), Peru (2008), Ukraine (2016), and the United States (through NAFTA (1992)); while the one with the EU (2016) is applied provisionally. Among these, the FTAs with Costa Rica, EFTA, Israel, Jordan, and Ukraine do not include investment chapters.

${ }^{21}$ The TPP had the same parties as the CPTPP with the United States. The CUSMA is the new name for the renegotiated NAFTA.

${ }^{22}$ Canada has ongoing FTA negotiations with the following countries and groupings: the Caribbean Community (Antigua and Barbuda, Bahamas, Barbados, Belize, Dominica, Grenada, Guyana, Haiti, Jamaica, Montserrat, Saint Kitts and Nevis, Saint Lucia, Saint Vincent and the Grenadines, Suriname, Trinidad and Tobago), the Dominican Republic, three Central American countries (El Salvador, Guatemala, Nicaragua), India, Japan, MERCOSUR (Argentina, Brazil, Paraguay, Uruguay), Morocco, the Pacific Alliance (Chile, Colombia, Mexico, Peru), and Singapore. 
nearly C\$ 4.5 billion, while Chinese FDI into Canada reached approximately C\$ 10.9 billion. This represented a more than five-fold increase in bilateral FDI from 2005. Canadian investments in China grew by roughly 300 per cent from 1998 to 2007, while Chinese investments in Canada increased by about 170 per cent (Walsh \&Woods, 2012: pp. 1-2; Fuchs, 2013: p. 2). In 2017, Canadian FDI in China amounted to C\$ 10.7 billion, while Chinese FDI in Canada reached C\$ 16.4 billion (Government of Canada (b)). ${ }^{23}$

Within the past few years, China has invested heavily in Canadian natural resources. In particular, following a review under the Investment Canada Act, Nexen Inc, an oil and gas company based in Calgary, Alberta, with major assets in oil sands, was acquired in 2012 by the state-owned China National Offshore Oil Corporation (CNOOC Ltd). The transaction, of roughly C $\$ 15.1$ billion, was the largest foreign takeover ever by a Chinese firm (Knigge, 2013: p. 1). ${ }^{24}$ This acquisition not only raised significant concerns in Canada, it also coincided with the successful conclusion of the Canada-China BIT negotiations. In such context, the ratification of the Canada-China BIT stirred a debate within Canada of an intensity unseen since the Canada-United States Free Trade Agreement in the late 1980 s.

The BIT negotiations between Canada and China began in 1994, then, slowed as China prepared for accession to the World Trade Organization (WTO) and as Canada drafted its 2004 BIT model. The negotiations resumed in September 2004 and final talks were held in January 2012. The Canada-China BIT was signed on 9 September 2012 in Vladivostok, Russia, during the Asia-Pacific Economic Cooperation Leaders' Meeting and brought into force on 1 October $2014 .^{25}$ In September 2016, the two countries announced the launch of exploratory discussions for a possible Canada-China FTA (Government of Canada (c)). In this regard, Canada has already concluded three FTAs, with Panama, Peru and Ukraine, that followed the conclusion of BITs. Reminiscent of the process that led to their BIT, however, the discussions and eventual FTA negotiations between Canada and China are likely to be (more) arduous (see: Leblond, 2017; Stephens, 2018).

The Canadian model provides for BITs to be terminated on one year's notice, with no minimum duration, plus a 15-year survival clause for existing investments at the time of termination (FIPA Model, Article 52.3). On the other hand, the Canada-China BIT is to be in force for at least 15 years, with a one-year termination notice and a 15-year survival clause (Canada-China BIT, Article 35), ${ }^{23}$ For more on Canada's economic relations with China, see: Tiagi \& Zhou (2009); Cao \& Poy (2011). On China's investment policy, see: Nicolas (2012); Berger (2015); Copper (2016). With over 100 BITs reached with a variety of countries since the early 1980s, China is among the states with the highest number of such agreements. In addition, besides those with its two special administrative regions (Hong Kong and Macau) and Taiwan, China has signed 13 FTAs with various countries and groupings, such as the Association of Southeast Asian Nations, Australia, Pakistan, Peru, Singapore, South Korea, and Switzerland (see UNCTAD (a)).

${ }^{24}$ On China's interest in foreign (both inward and outward) investment, especially in natural resources, see: Deng (2007); Buckley (2010); Deng, Yang, Wang, \& Doyle (2017).

${ }^{25}$ For more on the Canada-China BIT negotiations and provision preferences, see Carter (2009). 
giving it a relatively long minimum lifespan of 31 years (Van Harten, 2014b: pp. 43-46). Among all Canadian BITs, only four have such a minimum lifespan. ${ }^{26}$

\section{The Canadian BIT Model and the Canada-China BIT: Substantive Provisions}

The BIT model and almost all Canadian IIAs (FIPA Model, Articles $3 \& 4$ ) provide for foreign investment protection at the pre-establishment phase. The national treatment provision of the Canada-China BIT, however, applies only to the post-establishment phase of investments, i.e., after they have been made. Article 6 specifically excludes the terms "establishment" and "acquisition" from its wording, so that national treatment is only accorded to investors and covered investments with regard to their "expansion, management, conduct, operation and sale or other disposition"(Canada-China BIT, Article 6). Hence, there is no right of establishment and parties keep their respective rights to block new investments in their territory (Walsh \& Woods, 2012: p. 2; Côté, 2013: pp. 370-371; De Mestral, 2014: p. 1). The Canada-China BIT further restricts national treatment by limiting the application of the concept of "expansion" to "sectors not subject to a prior approval process under the relevant sectoral guidelines and applicable laws, regulations and rules in force at the time of expansion" (Canada-China BIT, Article 6.3). This preserves parties' right to impose certain prescribed formalities and other information requirements upon the "expansion" of investments in specified sectors (Walsh \& Woods, 2012: p. 2).

Unlike the BIT model and most Canadian IIAs (FIPA Model, Article 7), no list of restrictions on specific performance requirements is provided in the BIT with China (Canada-China BIT, Article 9). Parties simply reiterate their obligations under the WTO Agreement on Trade-Related Investment Measures (TRIMs), a more modest standard (WTO, Article $2 \&$ Annex).Thus, while many specific requirements are prohibited in both the Canadian BIT model and TRIMs, such as requiring of an enterprise that the volume or value of its imports be related to those of its exports, the TRIMs does not forbid technology transfer agreements (Walsh \& Woods, 2012: p. 4).

For Van Harten (2014a: p. 1), the Canada-China BIT is unique for its non-reciprocal elements to China's advantage. This goes beyond the usual non-reciprocity between capital-exporting and capital-importing countries. The Canada-China BIT involves both a formal non-reciprocity in the terms of the treaty, as well as effective non-reciprocity. While the national treatment obligation does not apply to the pre-establishment phase of an investment, the Canada-China BIT does extend MFN treatment to the pre-establishment stage (Canada-China BIT, Article 5). In the few Canadian BITs that exclude

\footnotetext{
${ }^{26}$ Eight other Canadian BITs provide for some variation from the BIT model with respect to duration: a minimum duration of ten years (Hungary, Poland, and Tanzania) and 15 years (China, Egypt); a survival clause of ten years (Ukraine) and 20 years (Hungary, Kuwait, Lebanon, Poland, and Russia).Thus, the BITs with China, Egypt, Hungary and Poland have a minimum lifespan of 31 years.
} 
pre-establishment national treatment, this exclusion applies as well to the MFN obligation. Unlike China, Canada has granted pre-establishment national treatment rights to foreign investors from third countries under other BITs, causing the MFN clause in the Canada-China BIT to extend these rights to Chinese investors. This represents an extraordinary concession as it ensures a derivative right of market access only to Chinese investors in Canada (Van Harten, 2014b: pp. 16-20).

Yet, in all its IIAs Canada has preserved its right to review foreign investments under the Investment Canada Act and such decisions are not subject to the treaties' dispute settlement provisions. This significantly restricts the right of establishment in Canada of foreign investors (Côté, 2012: pp. 300, 303), including the one that could be invoked by Chinese investors on the basis of the MFN clause. Toward Canada's decisions on establishment, the MFN obligation implies that there could be no discrimination among foreign investors based on their nationalities (Côté, 2013: p. 372). It is also not entirely clear that the MFN clause in the Canada-China BIT can be used in the absence of concrete discrimination between a Chinese investor and a third-country investor (see Batifort \& Heath, 2017: p. 909). ${ }^{27}$

Besides, the Canadian BIT model includes an exception precluding MFN reference to previous treaties as well as to existing and future FTAs or customs unions (FIPA Model, Annex III). The MFN obligation in Canada's BITs, thereby, has been made prospective, so as not to extend to treatment accorded under existing treaties (Newcombe, 2004: p. 4; Peterson, 2006: p. 7). This is intended to prevent investors from relying on the MFN clause to "cherry pick" the most favourable selection of rights offered in a foreign government's previous treaties. On the other hand, in the Canada-China BIT, such exception clause, if it still applies to existing and future PTAs, is restricted to international agreements in force prior to 1 January 1994, the day the NAFTA came into effect (Canada-China BIT, Article 8.1). Hence, the MFN obligation is expressly extended beyond any treatment given to third-state investors in future treaties to include any treatment given in previous treaties since 1994 (Van Harten, 2014b: pp. 28-29).

From a testimony of Vernon MacKay, the Canadian lead negotiator of the Canada-China BIT, the temporal "reach-back" clause on MFN treatment is meant to enable Canadian investors in China to take advantage of some Chinese BITs from the early 2000s, whose standards, especially on fair and equitable treatment, are very broadly worded so as to potentially offer more protection (quoted in Van Harten, 2014b: pp. 33-34). Such reach-back on MFN treatment also casts doubts as to the applicability of various provisions and safeguards included in Canadian IIAs since 2001 in the light of the implementation of NAFTA's investment rules and investor-state dispute settlement mechanism, notably as regards the minimum standard of treatment (Carter, 2009: pp.

\footnotetext{
${ }^{27}$ The author is grateful to an anonymous reviewer for raising these two points.
} 
232-233; Mann, 2013; Van Harten, 2014b: pp. 12-13, 27-34). The author of this article verified that of 20 Canadian BITs concluded since 2000, eight include this reach-back provision; with only one (with Jordan), however, prior to the conclusion of the Canada-China BIT. Beyond, unlike the BIT model, the Canada-China BIT provides that, for greater certainty, the MFN obligation does not encompass the investor-state dispute settlement mechanisms in other IIAs (Canada-China BIT, Article 5.3). Since 2000, five of 20 Canadian BITs provide for such exclusion; although only one (with Peru) before the Canada-China BIT was concluded. This exclusion also corresponds to China's recent BIT practice (Carter, 2009: p. 249).

More generally, the interpretation of MFN clauses in investment treaties has raised key issues, especially with the proliferation of BITs and cases of investor-state arbitration (UNCTAD, 2010; Cole, 2012; ILC, 2015; Gazzini, 2016; Nikièma, 2017; Batifort \& Heath, 2017; Pérez-Aznar, 2017; Schill, 2017; AJIL, 2018). The central question has been whether any rights contained in a treaty with a third state, which are more beneficial to an investor, could be relied upon by such an investor by virtue of an MFN clause. The past two decades of arbitration practice have tilted heavily toward such possibility, but this has provoked a debate as to the scope and effect of MFN clauses in investment treaties. In particular, with the other two states parties to the NAFTA, Canada has repeatedly challenged the use of MFN to import standards of treatment from third-party treaties (Batifort \& Heath, 2017: p. 899). This is something toward which Canada has proved particularly sensitive as the NAFTA party subject to the highest number of investor claims. Arguably without (much) effect on the Canada-China BIT, but reflective of Canadian intent, the exception to the MFN clause in the CETA stipulates that, "for greater certainty," "treatment" does not cover investor-state procedures and substantive obligations in other IIAs; in the latter case, "absent measures adopted or maintained by a Party pursuant to those obligations," i.e., actual cases of discrimination (CETA, Article 8.7.4).

The non-reciprocal character of the Canada-China BIT also owes to the more extensive liberalization and regulatory transparency of the Canadian economy. As in all Canadian IIAs, the Canada-China BIT excludes from its post-establishment national treatment obligation any existing non-conforming measure, including "law, regulation, rule, procedure, decision, requirement, administrative action, or practice," of either party that discriminates against the other's investors (Canada-China BIT, Articles 1.6 \& 8.2). Yet, in this particular case, this has for effect to lock in an un-level playing field between Canada and China (Van Harten, 2014a: pp. 1-2; 2014b: pp. 24-27). The Canada-China BIT as well has a broader carve-out from dispute settlement provisions for investment screening decisions by China. While Canada's carve-out is limited to federal decisions under the Investment Canada Act (FIPA Model, Annex IV), the China's one pertains to any of its "Laws, Regulations and Rules relating to the regulation of foreign investment"(Canada-China BIT, Annex D.34), i.e., at any level of 
government and without thresholds or other limitations (Van Harten, 2014a: p. 2; 2014b: pp. 20-24).

\section{The Canadian BIT Model and the Canada-China BIT: Investor-State Dispute Settlement Provisions}

Following the 2004 BIT model, Canadian BITs (and FTAs) provide for a high level of transparency in the investor-state dispute settlement process. This includes open hearings, arbitral awards to be publicly available, and, unless the disputing parties otherwise agree, all documents submitted to, or issued by, the tribunal (FIPA Model, Article 38). In the Canada-China BIT, however, the transparency of the arbitration process is somewhat more limited. The arbitral award is the only document that must be made available to the public, subject, as usual, to the deletion of confidential information. All other documents are to be made publicly available only if a disputing party determines that it is in the public interest to do so. Furthermore, the arbitral proceedings are only to be open to the public if, after consulting with a claimant, a disputing party considers it in the public interest (Canada-China BIT, Article 28).

Hence, the Canada-China BIT allows either government to settle an investor claim without public knowledge (Van Harten, 2014a: p. 2). In accordance with their favoured approaches, Ottawa can make arbitration cases against Canada public, while Beijing can keep cases against China under wraps. As a whole, in terms of transparency, this represents a departure from the Canadian BIT model, so as to respond to China's traditionally more restrictive approach to public access in proceedings (Boscariol \& Potter, 2012: p. 4; Knigge, 2013: p. 4; Walsh \& Woods, 2014: p. 2; see also Van Harten, 2014b: pp. 40-43). Conversely, even if their application is left at the parties' discretion, the inclusion of Canadian transparency standards for investor-state dispute resolution in the Canada-China BIT represents a concession from Chinese authorities and may lead to (more) transparent arbitration proceedings.

The Canada-China BIT also contains party-specific requirements with respect to the conditions precedent to submission of a claim to arbitration. When a Chinese measure is at issue, an investor must first make use of China's domestic administrative reconsideration procedure. An arbitration claim may only be submitted after four months have elapsed without resolve from the procedure. In case an investor has initiated a case before any Chinese court, the claim may be submitted only after it has been withdrawn and before judgment has been rendered (Canada-China BIT, Annex C.21). These more demanding conditions in China's case further limit the right to arbitration for Canadian investors compared with their Chinese counterparts, which is unusual within BITs (Côté, 2013: p. 380)

In terms of governing law, while the Canadian BIT model provides for arbitral tribunals to decide on issues in dispute in accordance with the said agreement and applicable rules of international law (FIPA Model, Article 40), the Can- 
ada-China BIT also specifies to take into consideration, where relevant and as appropriate, the law of the host state party (Canada-China BIT, Article 30). It is not clear at which country's request this innovation was introduced, ${ }^{28}$ which has figured in two subsequent Canadian FTAs, with Colombia and the EU.

As regards interim measures of protection, whereas the Canadian BIT model uses the words "a Tribunal may order" (FIPA Model, Article 43), the Canada-China BIT, in its Article 31, stipulates that "a Tribunal may recommend" such a measure (emphasis added). Thus, it appears that an arbitral tribunal is to have less power or authority to provide for interim measures of protection under the Canada-China BIT (Walsh \& Woods, 2014: p. 3).

\section{Conclusion}

From the late 1980s, Canada has joined other states in the conclusion of BITs and other IIAs with different countries from all continents. As one of its kind, the successful negotiation of the Canada-China BIT in 2012 raised controversy in Canada. The Canadian BIT with the Middle Kingdom also departs in some key instances from Canada's BIT model. This is notably the case with respect to performance requirements. Instead of a list of specific prohibitions, the Canada-China BIT simply refers to the parties' multilateral TRIMs obligations.

The main departure from Canada's foreign investment policy, however, pertains to the absence of a right of establishment, reflecting China's usual BIT practice (Côté, 2013: p. 371). ${ }^{29}$ The national treatment clause is restricted to the post-establishment phase of an investment, but such restriction does not apply to the MFN provision, which also includes the "establishment" and "acquisition" of investments. This unique feature of the Canada-China BIT has led to disagreements among legal scholars and analysts as to the scope of its implications. Unlike China, Canada has granted pre-establishment rights to foreign investors under its BITs. For Van Harten (2014b: pp. 16-20), this entails a right of market access only to Chinese investors in Canada. On the other hand, Côté (2012: pp. 300,303 ) highlights that Canada's preserved right to review foreign investments and, notably, the exclusion of its investment screening decisions from dispute settlement provisions, considerably limit such ensuing right of establishment.

There is also in the Canada-China BIT an exception precluding MFN reference to treaties in force prior to 1 January 1994. The MFN clause, thus, is made applicable to treatment afforded to third-state investors under post-1993 Canadian and Chinese BITs. This notably allows Canadian investors to benefit from enhanced protection under some previous Chinese BITs (Van Harten, 2014b: pp. 28-29, 33-34). Yet, the Canadian government has recently agreed in the CETA to preclude the "importation" of standards of treatment from third-party treaties. As another key difference from Canada's BIT model, this reach-back clause has also led to conflicting interpretations as to its implications. It makes it

${ }^{28}$ For further considerations on this, see Côté (2013: pp. 381-382).

${ }^{29}$ As the basis of its ongoing BIT negotiations with the United States and the EU, China in 2013 conceded to "pre-establishment national treatment" (Wang, 2017: p. 3). 
difficult, as well, to discern Canada's intentions and views concerning the MFN clause in the Canada-China BIT.

Even though the Canada-China BIT, like all Canadian IIAs, exempts existing non-conforming, or discriminatory, measures, in view of the greater liberalization and regulatory transparency of the Canadian economy, this more clearly involves a degree of non-reciprocity to China's advantage. Furthermore, while the investment screening decisions exempted from dispute settlement provisions are limited in Canada's case to federal decisions under the Investment Canada Act, the Chinese ones relate to any measures regulating foreign investment, at all levels of government and without thresholds or other limitations.

In terms of procedural provisions, although Canada's transparency standards for investor-state arbitration figure in the Canada-China BIT, their actual application is at the parties' discretion. As regards the conditions precedent to submission of a claim to arbitration, only Canadian investors must first make use of China's domestic administrative reconsideration procedure. Moreover, while the governing law for investor-state arbitration is the said treaty and applicable rules of international law, the Canada-China BIT also allows for the consideration of domestic law. Finally, an arbitral tribunal is to have less power to provide for interim measures of protection.

The key objective of BITs has been to protect investments from developed countries in developing and/or non-Western countries, and so is the case for Canada's BIT with China. Yet, another central objective of the Canada-China BIT has been to attract Chinese investments. In this respect, the Canada-China BIT is meant to help a two-way economic relationship develop to a greater extent. The Canada-China BIT also further confirms Chinese willingness to accept elements of Western states' IIAs (Van Harten, 2014a: p. 2). When signed in 2012, the Canada-China BIT was the highest-standard investment agreement China ever entered, according to Chinese analysts (Wang, 2017: p. 5).

Concurrently, China is an important trade and investment partner. Apart from its IIAs involving some major OECD countries, no other Canadian BIT approaches the economic significance of the Canada-China BIT. It is also for Canada the first (and so far only) BIT where it finds itself on the capital-importing side. Indeed, during the 2008-2012 period, Chinese investments in Canada exceeded Canadian investments in China by a ratio of about 3 to 1 (Van Harten, 2014b: pp. 47-48). These elements positioned Canada as the demandeur vis-à-vis the big emerging power. In turn, this may explain some crucial concessions discussed in this article and, thus, departures from the Canadian investment template.

\section{Acknowledgements}

This article is an updated and expanded version of a paper presented at the $24^{\text {th }}$ World Congress of the International Political Science Association, Poznań, Poland, 23-28 July 2016. The author is grateful to two anonymous reviewers for their comments. 


\section{Conflicts of Interest}

The author declares no conflicts of interest regarding the publication of this article.

\section{References}

FIPA Model (2004). Agreement between Canada and for the Promotion and Protection of Investments. https://www.italaw.com/documents/Canadian2004-FIPA-model-en.pdf

Canada-China BIT (2012). Agreement between the Government of Canada and the Government of the People's Republic of China for the Promotion and Reciprocal Protection of Investments. (Canada-China BIT). Signed 9 September 2012, Effective 1 October 2014 .

https:/international.gc.ca/trade-commerce/trade-agreements-accords-commerciaux/a gr-acc/china-chine/fipa-apie/index.aspx?lang=eng\&_ga=2.147378805.313717083.15550 69783-2088686874.1538764564

American Journal of International Law (AJIL) (2018). Symposium on Simon Batifort and J. Benton Heath, "The New Debate on the Interpretation of MFN Clauses in Investment Treaties: Putting the Brakes on Multilateralization”. AJIL Unbound, 112. https://doi.org/10.1017/ajil.2017.77

https://www.cambridge.org/core/journals/american-journal-of-international-law/ajil-u nbound-by-symposium/simon-batifort-and-j-benton-heath-the-new-debate-on-the-int erpretation-of-mfn-clauses-in-investment-treaties-putting-the-brakes-on-multilateralization

Batifort, S., \& Heath, J. B. (2017). The New Debate on the Interpretation of MFN Clauses in Investment Treaties: Putting the Breaks on Multilateralization. American Journal of International Law, 111, 873-913.

Berger, A. (2015). Hesitant Embrace: China's Recent Approach to International Investment Rule-Making. Journal of World Investment \& Trade, 16, 843-868. https://doi.org/10.1163/22119000-01606003

Bonnitcha, J., Poulsen, L. N. S., \& Waibel, M. (2017). The Political Economy of the Investment Treaty Regime. Oxford: Oxford University Press.

Boscariol, J. W., \& Potter, S. V. (2012). A Primer on the New China-Canada Bilateral Investment Treaty. McCarthy Tetrault, 3 October.

https://www.mccarthy.ca/en/insights/articles/primer-new-china-canada-bilateral-inves tment-treaty

Buckley, P. J. (2010). Foreign Direct Investment, China and the World Economy. Basingstoke: Palgrave Macmillan. https://doi.org/10.1057/9780230248328

Cao, H., \& Poy, V. (2011). The China Challenge: Sino-Canadian Relations in the 21st Century. Ottawa: University of Ottawa Press.

Carter, J. (2009). The Protracted Bargain: Negotiating the Canada-China Foreign Investment Promotion and Protection Agreement. Canadian Yearbook of International Law, 47, 197-260.

Cole, T. (2012). The Boundaries of Most Favored Nation Treatment in International Investment Law. Michigan Journal of International Law, 33, 537-586.

Collins, D. (2016). An Introduction to International Investment Law. Cambridge: Cambridge University Press. https://doi.org/10.1017/CBO9781316675687

Comprehensive Economic and Trade Agreement (CETA). Signed 30 October 2016, Effective (Provisionally) 21 September 2017. 
https://international.gc.ca/trade-commerce/trade-agreements-accords-commerciaux/a gr-acc/ceta-aecg/text-texte/toc-tdm.aspx?lang=eng

Convention on the Settlement of Investment Disputes between States and Nationals of Other States (ICSID Convention). Signed 18 March 1965, Effective 14 October 1966. https://icsid.worldbank.org/en/Documents/icsiddocs/ICSID\%20Convention\%20Englis $\underline{\text { h.pdf }}$

Copper, J. F. (2016). China's Foreign Aid and Investment Diplomacy (Vols. 1-3). Basingstoke \& New York: Palgrave Macmillan.

Côté, C.-E. (2006). Digest of International Economic Law in 2004: III. Investissement. Canadian Yearbook of International Law, 43, 486-503.

Côté, C.-E. (2012). Le Canada et l'investissement direct étranger: Entre ouverture et inquiétude. In M. Arès, \& E. Boulanger (Eds.), L'investissement et la nouvelle économie mondiale: Trajectoires nationales, réseaux mondiaux et normes internationales (pp. 241-313). Brussels: Bruylant.

Côté, C.-E. (2013). Digest of International Economic Law in 2012: III. Investissement. Canadian Yearbook of International Law, 50, 363-382.

De Mestral, A. (2014). The Canada-China BIT 2012: Perspectives and Implications. Columbia FDI Perspectives No. 129, 2 September.

http://ccsi.columbia.edu/files/2013/10/Perspective-de-Mestral-Sep-2-2014-Publication.pdf

Deng, P. (2007). Investing for Strategic Resources and its Rationale: The Case of Outward FDI from Chinese Companies. Business Horizons, 50, 71-81.

https://doi.org/10.1016/j.bushor.2006.07.001

Deng, P., Yang, X., Wang, L., \& Doyle, B. (2017). Chinese Investment in Advanced Economies: Opportunities and Challenges. Thunderbird International Business Review, 59, 461-471. https://doi.org/10.1002/tie.21903

Dolzer, R., \& Schreuer, C. (2012). Principles of International Investment Law (2nd ed.). Oxford: Oxford University Press. https://doi.org/10.1093/law/9780199651795.001.0001

Dugan, C. F., Rubins, N. D., Wallace Jr., D., \& Sabahi, B. (2008). Investor-State Arbitration. Oxford: Oxford University Press.

https://doi.org/10.1093/law:iic/9780379215441.book.1

Fortier, L. Y. (2009). The Canadian Approach to Investment Protection: How Far We Have Come! In C. Binder, U. Kriebaum, A. Reinisch, \& S. Wittich (Eds.), International Investment Law for the 21st Century: Essays in Honour of Christoph Schreuer (pp. 525-543). New York: Oxford University Press.

Fuchs, P. (2013). Open for Business. National, Canadian Bar Association, January-February.

http://nationalmagazine.ca/Articles/January___February_2013/Open_for_business.asp $\underline{\mathrm{x}}$

Gazzini, T. (2016). Interpretation of International Investment Treaties. Oxford \& Portland, OR: Hart Publishing.

Government of Canada (a). Trade and Investment Agreements. https://www.international.gc.ca/trade-commerce/trade-agreements-accords-commerci aux/agr-acc/index.aspx?lang=eng

Government of Canada (b). Factsheet: China. https://www.canadainternational.gc.ca/china-chine/bilateral_relations_bilaterales/Chin a-FS-Chine-FD.aspx?lang=eng

Government of Canada (c). Exploratory Discussions on a Possible Canada-China Free 
Trade Agreement.

https://international.gc.ca/trade-commerce/trade-agreements-accords-commerciaux/a gr-acc/china-chine/fta-ale/background-contexte.aspx?lang=eng\&_ga=2.114699207.194 6135890.1549559098-2088686874.1538764564

International Law Commission (ILC) (2015). Study Group on the Most-Favoured-Nation Clause: Final Report. UN Doc. A/CN.4/L.852. United Nations, General Assembly, International Law Commission, 67th Session.

http://legal.un.org/docs/?symbol=A/CN.4/L.852

Knigge, M. (2013). China Investment Deal Raises Red Flags in Canada. DW Made for Minds, 26 April.

http://www.dw.com/en/china-investment-deal-raises-red-flags-in-canada/a-16775194

Leblond, P. (2017). Toward a Free Trade Agreement with China: Opportunities, Challenges and Building Blocks for Canada. Waterloo, ON: Centre for International Governance Innovation.

https://www.cigionline.org/sites/default/files/documents/China\%20Canada\%20Trade.p df

Lim, C. L., Ho, J., \& Paparinskis, M. (2018). International Investment Law and Arbitration: Commentary, Awards and Other Materials. Cambridge: Cambridge University Press.

Mann, H. (2013). The Canada-China Investment Treaty Sleight of Hand. Embassy News, 8 January.

https://www.hilltimes.com/global/2013/01/08/the-canada-china-investment-treaty-slei ght-of-hand/33048

McIlroy, J. (2004). Canada's New Foreign Investment Protection and Promotion Agreement: Two Steps Forward, One Step Back? Journal of World Investment \& Trade, 5, 621-646.

McLachlan, C., Shore, L., \& Weiniger, M. (2017). International Investment Arbitration: Substantive Principles (2nd ed.). Oxford: Oxford University Press.

Newcombe, A. (2004). Canada's New Model Foreign Investment Protection Agreement. Victoria: Faculty of Law, University of Victoria. https://www.italaw.com/documents/CanadianFIPA.pdf

Newcombe, A. (2017). Canadian Investment Treaty Policy: Stay the Course on Progressive Developments. In S. Tapp, A. Van Assche, \& R. Wolfe (Eds.), Redesigning Canadian Trade Policies for New Global Realities (pp. 411-444). Montreal: Institute for Research on Public Policy.

http://irpp.org/research-studies/canadian-investment-treaty-policy

Newcombe, A., \& Paradell, L. (2009). Law and Practice of Investment Treaties: Standards of Treatment. Alphen aan den Rijn: Kluwer Law International.

Nicolas, F. (2012). Chine et investissements internationaux: Vers une normalisation. In M. Arès, \& E. Boulanger (Eds.), L'investissement et la nouvelle économie mondiale: Trajectoires nationales, réseaux mondiaux et normes internationales (pp. 411-434). Brussels: Bruylant.

Nikièma, S. H. (2017). The Most-Favoured-Nation Clause in Investment Treaties. International Institute for Sustainable Development Best Practices Series.

https://www.iisd.org/sites/default/files/publications/mfn-most-favoured-nation-clausebest-practices-en.pdf

Organization for Economic Cooperation and Development (OECD) (2018). FDI in Figures.

http://www.oecd.org/investment/investment-policy/FDI-in-Figures-April-2018.pdf 
Pérez-Aznar, F. (2017). The Use of Most-Favoured-Nation Clauses to Import Substantive Treaty Provisions in International Investment Agreements. Journal of International Economic Law, 20, 777-805. https://doi.org/10.1093/jiel/jgx034

Peterson, L. E. (2006). Evaluating Canada's 2004 Model Foreign Investment Protection Agreement in Light of Civil Society Concerns. Canadian Council for International Co-Operation.

http://archive.ccic.ca/_files/en/what_we_do/trade_2006-06_foreign_investment_memo e.pdf

Salacuse, J. W. (2015). The Law of Investment Treaties (2nd ed.). Oxford: Oxford University Press.

Schill, S. W. (2017). MFN Clauses as Bilateral Commitments to Multilateralism: A Reply to Simon Batifort and J. Benton Heath. American Journal of International Law, 111, 914-935. https://doi.org/10.1017/ajil.2017.94

Schill, S. W., Tams, C. J., \& Hofmann, R. (2018). International Investment Law and History. Cheltenham \& Northampton: Edward Elgar. https://doi.org/10.4337/9781786439963

Sornarajah, M. (2017). The International Law on Foreign Investment (4th ed.). Cambridge: Cambridge University Press. https://doi.org/10.1017/9781316459959

Stephens, H. (2018). Canada's Progressive Trade Agenda and a Free Trade Agreement with China: Are They Incompatible? SPP Policy Brief 11:27, Calgary: School of Public Policy, University of Calgary.

https://d3n8a8pro7vhmx.cloudfront.net/cdfai/pages/4057/attachments/original/153910 6260/Canadas_Progressive_Trade_Agenda_and_a_Free_Trade_Agreement_with_Chin a_Are_They_Incompatible.pdf?1539106260

Tiagi, R., \& Zhou, L. (2009). Canada's Economic Relations with China. Vancouver: Fraser Institute.

Titi, C. (2013). The Evolving BIT: A Commentary on Canada's Model Agreement. Investment Treaty News, International Institute for Sustainable Development. https://www.iisd.org/itn/2013/06/26/the-evolving-bit-a-commentary-on-canadas-mode l-agreement

United Nations Conference on Trade and Development (UNCTAD) (a). Investment Policy Hub, IIAs by Economy, China. https://investmentpolicyhub.unctad.org/IIA/CountryOtherIias/42\#iiaInnerMenu

United Nations Conference on Trade and Development (UNCTAD) (2010). Most-Favoured-Nation Treatment. UNCTAD Series on Issues in International Investment Agreements II. New York \& Geneva: United Nations.

https://unctad.org/en/Docs/diaeia20101_en.pdf

United Nations Conference on Trade and Development (UNCTAD) (2018). World Investment Report 2018: Investment and New Industrial Policies. New York \& Geneva: United Nations. https://unctad.org/en/PublicationsLibrary/wir2018_en.pdf

Van Harten, G. (2014a). Canada's Non-Reciprocal BIT with China: Would the US or Europe Do the Same? Columbia FDI Perspectives No. 136, 8 December. http://ccsi.columbia.edu/files/2013/10/No-136-Van-Harten-FINAL.pdf

Van Harten, G. (2014b). The Canada-China FIPPA: Its Uniqueness and Non-Reciprocity. Canadian Yearbook of International Law, 51, 3-55.

Waibel, M., Kaushal, A., Chung, L., \& Balchin, C. (2010). The Backlash against Investment Arbitration: Perceptions and Reality. Alphen aan den Rijn: Kluwer Law International. 
Walsh, C., \& Woods, M. G. (2012). The Canada-China Foreign Investment Protection and Promotion Agreement: A Comparative Analysis to Canada's Model FIPA. HeenanBlaikie LLP.

http://www.mondaq.com/canada/x/213340/international+trade+investment/The+Can ada-

China+Foreign+Investment+Protection + And + Promotion+Agreement $+\mathrm{A}+$ Comparativ e+Analysis+To+Canadas+Model+FIPA

Walsh, C., \& Woods, M. G. (2014). The Canada-China Foreign Investment Protection and Promotion Agreement. Part II: Investor-State Dispute Settlement Provisions. Woods Lafortune LLP.

http://www.wl-tradelaw.com/the-canada-china-foreign-investment-promotion-and-pr otection-agreement-part-ii-investor-state-dispute-settlement-provisions

Wang, Y. (2017). China's BIT Progress and Implications for China-Canada FTA Talks. Policy Brief No. 104, Waterloo, ON: Centre for International Governance Innovation. https://www.cigionline.org/sites/default/files/documents/PB\%20no.104web.pdf

World Trade Organization (WTO). Agreement on Trade-Related Investment Measures (TRIMs). Signed 15 April 1994, Effective 1 January 1995.

https://www.wto.org/english/docs_e/legal_e/18-trims_e.htm 